\title{
Improvement of Strength of Concrete by Using Agricultural By-Products
}

\author{
Shubham Kumar Sarangi ${ }^{*}$ and Bijayalaxmi Naik ${ }^{2}$ \\ ${ }^{1}$ Centurion University of Technology and Management, Odisha, India \\ ${ }^{2}$ Gobind Ballav Pant University of Agriculture and Technology, \\ Pantnagar, Uttarakhand, India \\ *Corresponding author
}

\begin{tabular}{l} 
K e y w o r d s \\
Agricultural \\
byproducts, Rice \\
husk ash, silica \\
fume, silpozz, \\
Strength, concrete \\
\hline Article Info \\
\hline $\begin{array}{l}\text { Accepted: } \\
\text { 12 March } 2020 \\
\text { Available Online: } \\
\text { 10 April } 2020\end{array}$ \\
\hline
\end{tabular}

\section{A B S T R A C T}

In this modernized world the increase in the demand of construction and need of providing sustainable growth for the development materials has prompted designers and the developers to opt for new 'alternative substitutes' feasible for construction. Considering this objective use of agricultural by-products is very constructive. These agricultural byproducts namely silica fume (rice husk ash) and silpozz can be substituted instead of cement due to their pozzolanic behavior. In the present study, silica fume and silpozz were used as an admixture to cement in concrete and its properties were studied. The experimental study based upon the nature of silica fume and silpozz and its influence on the properties of concrete on replacement with $0,10,20,30$ and $40 \%$ by weight of cement. An attempt was made to test the strength parameters of concrete made with partial replacement of the cement by silica fume and silpozz. Test results indicated that 20-30\% replacement of silica fume and silpozz in concrete has improved the strength of concrete.

\section{Introduction}

Concrete is the main source of infrastructure. Over 5\% of global $\mathrm{CO}_{2}$ emissions can be credited to Portland cement production. To decrease the pollution due to production of cement, it can be partially replaced by green materials which have some pozzolanic characteristics. A number of green materials have been studied for replacement of cement partially like fly ash, ground nut shell ash etc. which has been successful. The present paper is focused on the replacement of cement partially with silica fume and silpozz which are byproducts of the rice husk.

India is one of the leading producers of rice. Globally paddy of about 600 million tons are being produced which accounts for an average annual production of 120 million tons 
of rice husk. In most cases, the husk being produced during the processing of rice is either burnt or dumped as a waste material. Rice husk ash contains $90 \%-95 \%$ of reactive silica and is a pozzolanic material. It has different physical and chemical properties. The product being obtained from rice husk ash is identified by the trade name silpozz/silica fume which is very much finer than cement. The increasing demand for fine and amorphous silica in the production of special cement and concrete mixes provides high strength and low permeability of concrete for use in construction works. Thus we can use silica fume and silipozz to meet the demand for amorphous silica.

The study from Faseyemi Victor Ajileye University of Ibadan, USA it was reviewed that cement replacement up to $10 \%$ with silica fume (Agricultural by-products) leads to increase in the compressive strength, for the C30 grade of concrete. From 15\% there is a decline in compressive strength for $3,7,14$ and 28 days during curing period. It was being observed that the compressive strength of C30 grade of concrete has risen from $16.15 \%$ to $29.24 \%$ and decreased from $23.98 \%$ to $20.22 \%$. The maximum replacement level of the silica fume is $10 \%$ for the C30 grade of concrete.

It is recommended that testing of concrete produced with micro silica concrete be extended to 56 or possibly 90 days to further determine the pozzolanic ability of the micro silica. Volume replacement methods are recommended to investigate the possibility of producing high strength concrete with micro silica.

\section{Materials and Methods}

Ordinary Portland cement (OPC) 53 grades was utilized as the main ingredient along with silica fume and silpozz as the replaced materials. Vicat apparatus was utilized for determining the normal consistency and the time of setting of Portland cement. The apparatus consists of an iron rod weighing about 300 grams, having a needle at each end, and supported by a frame with graduated scale to measure distance to which the needle penetrates into the cement.

Another instrument, universal testing machine (UTM), also known as universal tester, materials test framer or materials testing machine, was used to test the tensile strength and compressive strength of materials.

First the required materials were collected for the test such as cement, silpozz, silica fume (black and grey), water and other related accessories such as belchas, cement pan and so on. The required amounts of cement were weighed by using digital weighing machine. Cement was replaced by materials (silpozz, silica fume) with given percentage of $10 \%$, $20 \%, 30 \%$ and $40 \%$ by weight. Cement and replaced materials were mixed as shown in figure 1 by adding water in the ratio as specified by Indian standards. The mixing process was continued until the paste attained proper consistency.

Then the mortar was tested by vicat apparatus as shown in figure 2 , if the consistency was measured between $5-7 \mathrm{~mm}$ then it was acceptable, otherwise again the sample was prepared and the above process was repeated. Sample was put inside the cube with the help of tampering rod, so that the material would perfectly set inside the cube. Then for perfect settlement the cube was put on the sieve shaker machine. Cube was kept on rest for 48 hours, and then it was de-molded and cured in water for 14 days and then air cured for at least another week at room temperature. The compressive strength was measured through UTM (Universal testing machine) figure 3. This process was repeated for each sample. 


\section{Procedure}

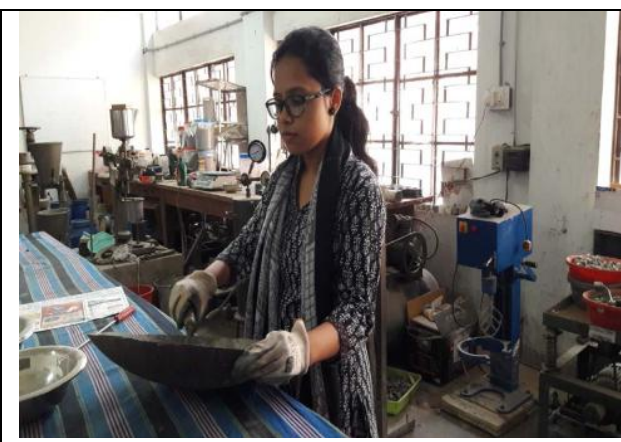

(i)

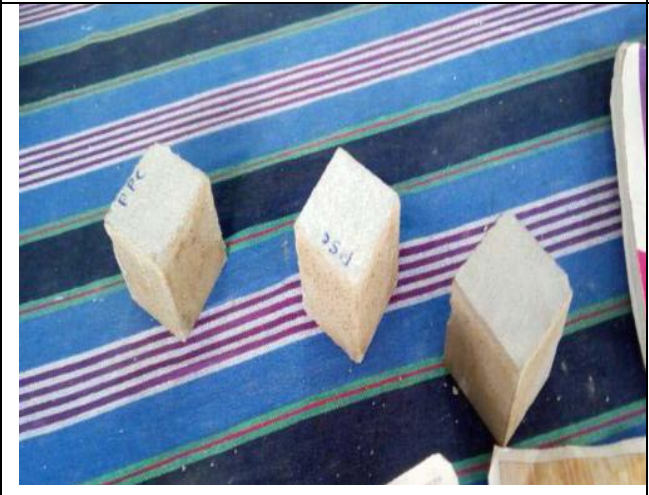

(v)

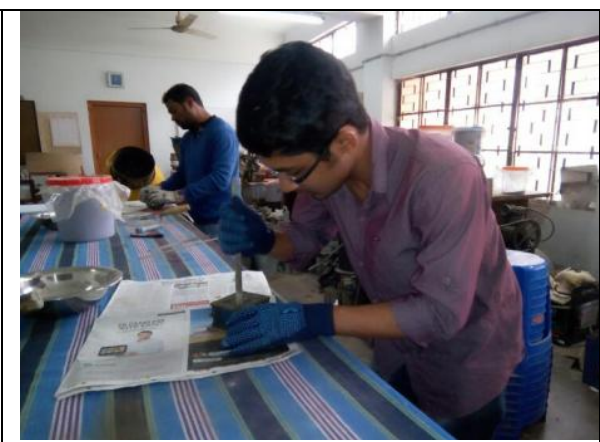

(ii)

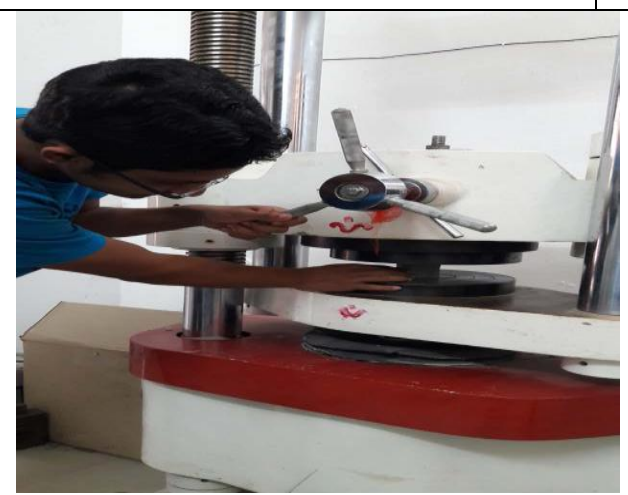

(vi)

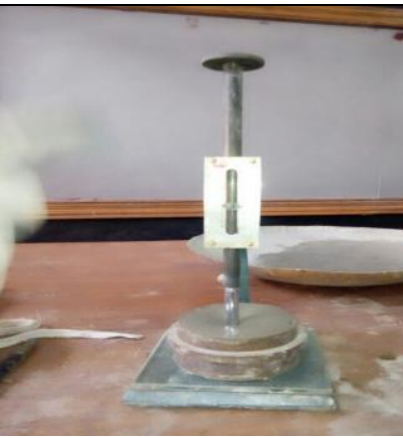

(iii)

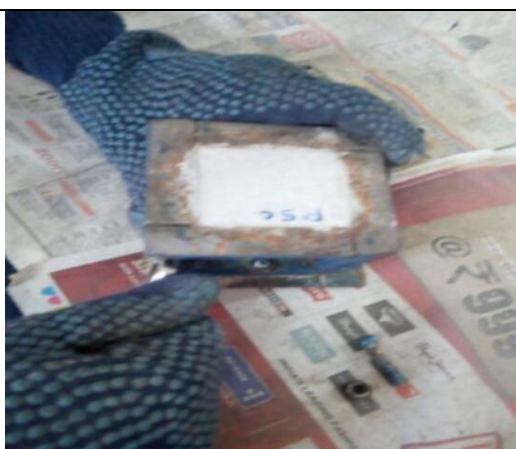

(iv)

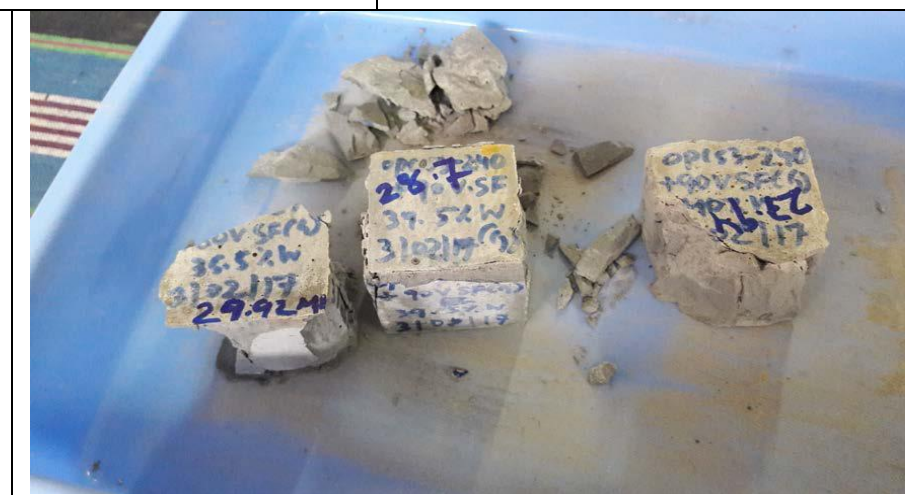

(vii)

\section{STEP WISE PROCEDURES}

(i) = Mixing of cement

(ii) = Preparing of cubes of cement

(iii) $=$ Vicat apparatus

(iv) $=$ Dismantling of cubes

(v) = Prepared cubes

(vi) = Testing of cubes by UTM

(vii) $=$ Tested cubes 


\section{Results and Discussion}

Measurements of applied force (load) and deformation of the specimen were generally not made directly upon the specimen. Instead, the electrical signals were being sent to a recorder device, typically a computer running data acquisition and analysis software. The UTM machines were digital controlled and PC-driven softwares. The typical load/deformation curves represent two components- force on the $\mathrm{Y}$-axis versus deformation on the $\mathrm{X}$-axis. All testing is done in accordance with specific ASTM and /or ISO standards.

On the basis of the results from the UTM, the following table was prepared which showed the strength of cubes produced from the various replacement of silpozz and silica fume. The following graphs were also made as per the given results (Table 1).

Table.1 Percentage of cement replacement along with corresponding strength

\begin{tabular}{|l|c|c|c|c|}
\hline $\begin{array}{l}\text { OPC 53 } \\
\text { (gm) }\end{array}$ & Cementre Placement (\%) & \multicolumn{3}{|c|}{ Strength(Mpa) } \\
\cline { 3 - 5 } & & $\begin{array}{c}\text { Silica Fume } \\
\text { (Black) }\end{array}$ & Silica Fume (Grey) & Silpozz \\
\hline 300 & 0 & 38 & 38 & 38 \\
\hline 270 & 10 & 45.15 & 29.92 & 34.55 \\
\hline 240 & 20 & 47.25 & 33 & 42.19 \\
\hline 210 & 30 & 31.18 & 46.22 & 27.79 \\
\hline 180 & 40 & 28.27 & 39.2 & 25.54 \\
\hline
\end{tabular}

\section{Silica Fume(Black)}

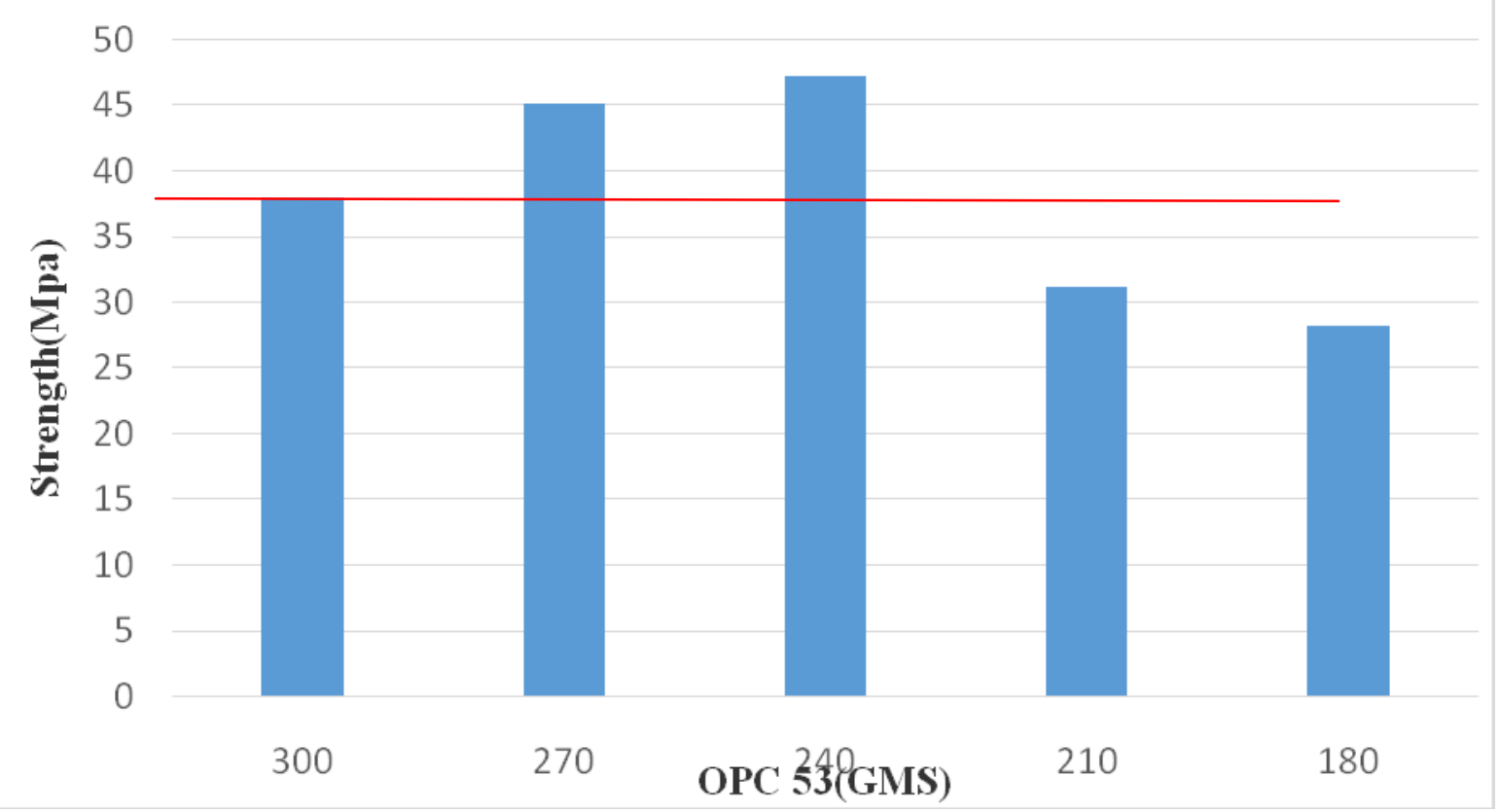

Graph.1 Strength (X-axis) verses amount of cement replaced (Y-axis) *red line represents the strength of ordinary cement without replacement 


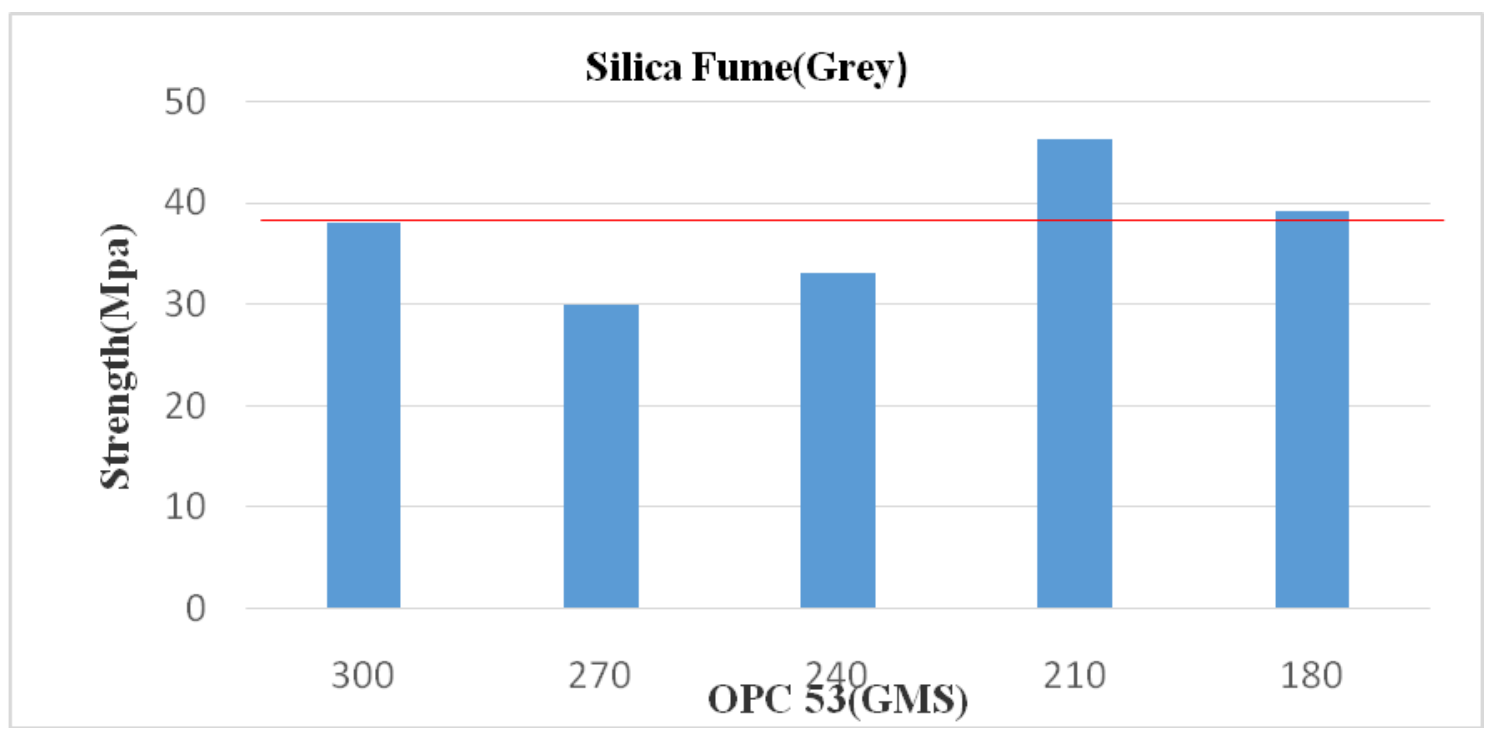

Graph.2 Strength (X-axis) verses amount of cement replaced (Y-axis)

*red line represents the strength of ordinary cement without replacement

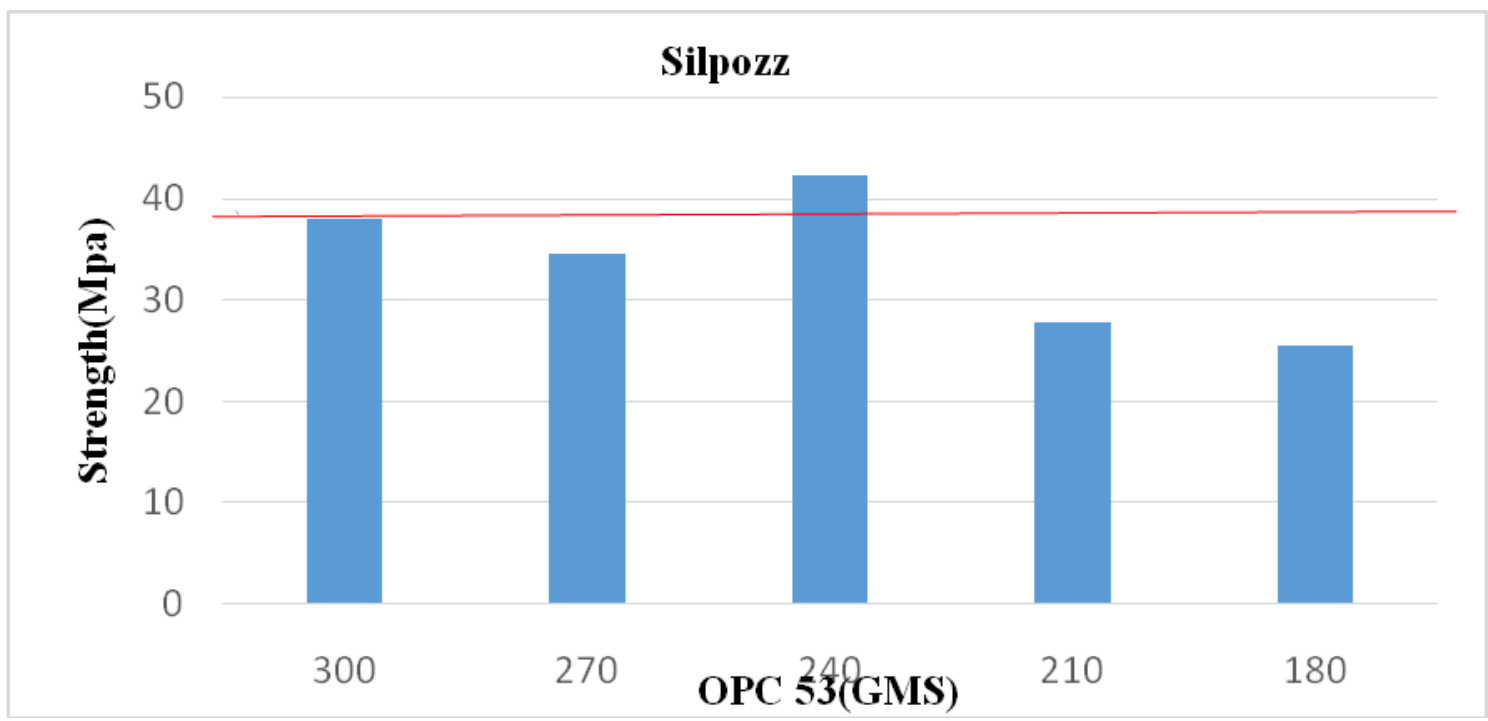

Graph.3 Strength (X-axis) verses amount of cement replaced (Y-axis)

*red line represents the strength of ordinary cement without replacement

Based on the study carried out on the strength behavior of cement replaced by agricultural by-products the following conclusions were drawn such as:

The strength attains maximum at $20 \%$ replacement of silica fume (Black).

It increases from $0-20 \%$ replacement after attaining maximum at $20 \%$ replacement and thereafter decreases.
Silica fume (Grey) cement showed maximum strength at $30 \%$ replacement.

In the case of silpozz the strength attains maximum at $20 \%$ replacement.

So, in this era of industrialization to bridge the gap between demand and supply level of cement, agricultural by-products can be replaced as a better substitute of cement successfully. 


\section{References}

Aditya Kumar Anupam et al., / Procedia Social and Behavioral Sciences 104 (2013): 264 - 273.

Ajileye, Faseyemi Victor (2012) Investigations on Microsilica (Silica Fume) As Partial Cement Replacement in Concrete, Global Journal of researches in engineering Civil And Structural engineering. Volume 12 Issue 1 Version 1.0.

Anupama, Aditya Kumar., Kumar, Praveen. And Ransinchung, G D. (2013) Use of Various Agricultural and Industrial Waste Materials in Road Construction, Science direct Elsevier. Procedia Social and Behavioral Sciences 104 (2013) $264-273$.

Arel, Hasan, Sahan and Aydin, Ertug (2018) Use of industrial and agricultural wastes in construction concrete, ACI materials journal. MS No. M-2016-238.R3.

Basha, E. A., Hashim, R., Mahmud, H. B. and Muntohar, A. S. (2005). Stabilization of residual soil with rice husk ash and cement Stabilization of residual soil with rice husk ash and cement. Construction and Building Materials, Vol. 19, 448453.

Bhanja S., Sengupta B. (2002), Investigations on the compressive strength of silica fume concrete using statistical methods, Cement and Concrete Research 32 (2002): $1391-1394$.

Cordeiro, G. C., Toledo Filho, R. D., Fairbairn, E. M. R. (2009). Effect of calcinations temperature on the pozzolanic activityof sugar cane bagasse ash. Construction and Building Materials. Vol. 23, 33013303.

Dhawan, P. K., Swami, R. K., Mehta, H. S., Bhatnagar, O. P., and Murty, A. V. R. S. (1994). Bulk utilization of coal ashes from road works. Indian highways, Vol. 22 (11), 21-30.
Dilip Kumar Singha Roy, AmitavaSil,(2012) Effect of Partial Replacement of Cement by Silica Fume on Hardened Concrete, International Journal of Emerging Technology and Advanced Engineering, ISSN 2250-2459, Volume 2 , Issue 8.

Gandhi, Rajiv. And Domke, pravin (2012) Improvement In The Strength Of Concrete By Using Industrial And Agricultural Waste, IOSR Journal of engineering. Vol. 2(4) pp: 755-759.

Ganesan, K., Rajagopal, K. and Thangavel, K. (2007). Evaluation of bagasse ash as supplementary cementitious material. Cement \& Concrete Composites, Vol. 29. 515524.

Ghutke S. Vishal, Bhandari S. Pranita,(2014), Influence of silica fume on concrete, IOSR Journal of Mechanical and Civil Engineering (IOSR-JMCE), PP. 44-47.

Govindarao, V. M. H. (1980). Utilization of rice husk - a preliminary analysis. Journal of Science and Industrial Research, 39(6). 495-515.

Goyal, A., Anwar, A.M., Kunio, H., Hidehiko, O. (2007). Properties of sugarcane bagasse ash and its potential as cement - Pozzolana binder. Twelfth International Colloquium on Structural and Geotechnical Engineering, 10-12 Dec. Cairo Egypt.

International Conference, Waste and Byproducts as Secondary Resources for Building Materials, 13-16 April, 1999, New Delhi, India.

IS 10262: 1982 Recommended Guidelines for Concrete Mix Design.

IS: 2386 (Part v) -1963, Methods of test for aggregates for concrete, Bureau of Indian standards, New Delhi, India.

IS: 456:2000, Plain and Reinforced Concrete", Code of Practice, Bureau of Indian Standards, New Delhi, 2000.

IS: 8112:2007, Specification for 43 Grade ordinary Portland cement, Bureau of 
Indian Standards, New Delhi. 2007.

Jha, J. N. and Gill, K. S. (2006). Effect of rice husk ash on lime stabilization. Journal of the Institution of Engineers (India), Vol. 87, 33-39.

Kennouche, S., Zerizer, A., Benmounah, A., Hami, B., Mahdad, M. and Benouali Bedjou, S. (2013). Formulation and characterization of self-compacting concrete with silica fume, Journal of Engineering and Technology Research, Vol. 5(5).

Kumar, A., Walia, B. S. and Bajaj, A. (2007). Influence of Fly Ash, Lime, and Polyester Fibers on Compaction and Strength Properties of Expansive Soil. Journal of Materials in Civil Engineering, 19(3). 242248.

Kumar, P. and Singh, S. P. (2008). Fiberreinforced fly ash subbases in rural roads. Journal of Transportation Engineering ASCE, 134(4). 171-180.
Mohamed A. Heba (2011) Effect of fly ash and silica fume on compressive strength of selfcompacting concrete under different curing conditions, Ain Shams Engineering Journal (2011).

Neville, A. M., Properties of Concrete, Fourth Edition, Prentice Hall, Harlow, UK, pp. 844, 1995.

Osinubi, K. J., Bafyau, V, and Eberemu, A. O. (2009). Bagasse Ash Stabilization of Lateritic Soil. Appropriate Technologies for Environmental Protection in the Developing World, Springer, 271-280.

Prabakar, J., Dendorkar, N. and Morchhale, R. K. (2004). Influence of fly ash on strength behavior of typical soils. Construction and Building Materials, Vol. 18. 263267.

Ranasinghe and Arjurna, P. (1993). Use of Rice Straw as Pozzolana. Master Thesis No. St-85-1, Asian Institute of Technology.

\section{How to cite this article:}

Shubham Kumar Sarangi and Bijayalaxmi Naik. 2020. Improvement of Strength of Concrete by Using Agricultural By-Products. Int.J.Curr.Microbiol.App.Sci. 9(04): 1544-1550. doi: https://doi.org/10.20546/ijcmas.2020.904.181 